\title{
Estrogen receptor a in cancer associated fibroblasts suppresses prostate cancer invasion via reducing CCL5, IL6 and macrophage infiltration in the tumor microenvironment
}

\author{
Chiuan-Ren Yeh', Spencer Slavin', Jun Da', lawen Hsu', Jie Luo', Guang-Qian Xiao², Jie Ding ', Fu-Ju Chou \\ and Shuyuan Yeh ${ }^{*}$
}

\begin{abstract}
Background: Cancer associated fibroblasts (CAF) play important roles in tumor growth that involves inflammation and epithelial cell differentiation. Early studies suggested that estrogen receptor alpha (ERa) was expressed in stromal cells in normal prostates and prostate cancer (PCa), but the detailed functions of stromal ERa in the PCa remain to be further elucidated.

Methods: Migration and invasion assays demonstrated the presence of high levels of ERa in CAF cells (CAF.ERa(+)) suppressed PCa invasion via influencing the infiltration of tumor associated macrophages. ERa decreased CAF CCL5 secretion via suppressing the CCL5 promoter activity was examined by luciferase assay. ERa decreased CCL5 and IL-6 expression in conditioned media that was collected from CAF cell only or CAF cell co-cultured with macrophages as measured by ELISA assay.

Results: Both in vitro and in vivo studies demonstrated CAF.ERa(+) led to a reduced macrophage migration toward PCa via inhibiting CAF cells secreted chemokine CCL5. This CAF.ERa(+) suppressed macrophage infiltration affected the neighboring PCa cells invasion and the reduced invasiveness of PCa cells are at least partly due to reduced IL6 expression in the macrophages and CAF.
\end{abstract}

Conclusion: Our data suggest that CAF ERa could be applied as a prognostic marker to predict cancer progression, and targeting CCL5 and IL6 may be applied as an alternative therapeutic approach to reduce M2 type macrophages and PCa invasion in PCa patients with low or little ERa expression in CAF cells.

Keywords: CAF, ERa, CCL5, IL6, Tumor associated macrophages, Prostate cancer

\section{Background}

Prostate cancer $(\mathrm{PCa})$ is the most frequently diagnosed cancer and second leading cause of cancer death in men in the United States [1]. PCa is a chronic type of tumor that requires a long time for small lesions to become clinically manifested compared to some other cancers [2]. Inflammation has been thought to be one of the key

\footnotetext{
* Correspondence: shuyuan_yeh@urmc.rochester.edu

1 George Whipple Lab for Cancer Research, Departments of Urology and Pathology, University of Rochester Medical Center, Rochester, NY 14642, USA

Full list of author information is available at the end of the article
}

pathogenic factors for $\mathrm{PCa}$ and there is an association between chronic inflammation and increased prevalence of PCa [3-6]. Furthermore, tumor associated macrophages (TAM) form a major component of the inflammatory infiltrates in both primary and secondary tumors [7] and can release growth factors, cytokines and chemokines to regulate tumor growth and invasion [8]. However, the detailed mechanisms how the interactions among stromal cells, TAM, and PCa cells could influence the growth and metastasis of PCa remain to be further elucidated. 
An earlier study suggested that cancer associated fibroblasts (CAF) may play important roles to influence $\mathrm{PCa}$ progression and invasion [9]. In the prostate tumor microenvironment (TME), PCa epithelial cells can produce some growth factors, such as TGF- $\beta$, PDGF and FGF, to influence/activate peripheral stromal cells that result in transformation of normal fibroblasts into CAF. Subsequently, CAF can then increase in population through transforming from normal fibroblasts [10], differentiation from bone marrow-derived mesenchymal stem cells [11] or by epithelial to mesenchymal transition (EMT). The important functions of CAF include the regulation of deposition of extracellular matrix (ECM), epithelial differentiation, tumor inflammation, and wound healing [12]. Ezer et al. demonstrated that CAF could mediate inflammation and angiogenesis by recruiting macrophages to stimulate angiogenesis, which may then promote tumor growth [13].

The existence of aromatase (to convert testosterone to estrogen) [14] and the finding of an increase in estrogen-to-androgen ratio in aging men [15] indicated that estrogens, in addition to androgens, could play important roles in PCa initiation and progression. Animal studies also demonstrated that $100 \%$ of rats being treated with $17 \beta$-estradiol $\left(E_{2}\right)$ plus testosterone for around 44 weeks had prostatic adenocarcinomas [16].

Estrogen action is mainly mediated through its specific nuclear receptors that regulate transcription of target genes via binding to the estrogen response element (ERE) or non-ERE mediated transactivation, as well as non-genomic regulations [17]. There are two major types of estrogen receptors (ERs), ER alpha $(E R \alpha)$ and ER beta $(E R \beta)[18,19]$. The two ER subtypes are structurally similar, consisting of the six common domains (A-F), but encoded by separate genes (ESR1 and ESR2). Immunostaining indicated that $\mathrm{ER} \alpha$ positive $[\mathrm{ER} \alpha(+)]$ staining was present in normal prostate stromal cells nuclei [20]. The function of stromal ER $\alpha$, however, remains largely unknown.

It has been well demonstrated that cancer related inflammation promotes cancer cells proliferation, migration and invasion through several pathways, including signal transduction activation, cytokines secretion and immune cells infiltration [21]. The TAM, M2 type, are the major players that link tumor related inflammation and tumor progression [22]. A variety of chemokines, like CCL2 and CCL5, have been detected in neoplastic tissues and associated with tumor associated immune cells formation and recruitment [23].

Using the in vitro co-culture system and in vivo mouse models, we studied CAF ER $\alpha$ roles in PCa invasion and found CAF ER $\alpha$ could inhibit PCa metastasis via suppression of macrophage infiltration and M2 type macrophages formation. This CAF.ER $\alpha(+) \rightarrow$ macrophages $\rightarrow$
PCa invasion pathway involves the modulation of CAF CCL5 and macrophages IL6 gene expressions. This finding supports the clinical observation that $\mathrm{PCa}$ patients with stromal ER $\alpha$ have better PSA free survival rates [24].

\section{Results \\ ERa in CAFs suppressed macrophage infiltration}

Early reports showed that ER $\alpha$ in stromal cells could affect the prostate development $[25,26]$. Another report showed that E2 plus testosterone treatment could stimulate the PCa initiation [27], however, the role of stromal ER $\alpha$ in the later stages of PCa progression and how it may affect immune cell infiltration and PCa metastasis is not well studied. Although the positive expression of ER $\alpha$ in the CAF is lower than in the benign component of human PCa tissues [28], the clinical correlation has been identified and one study showed patients with CAF.ER $\alpha(+)$ expression have better PSA free recurrence survival rate [24]. We isolated CAF from TRAMP mice prostate tumors, immortalized them by SV40 large T-antigen, and then studied how ER $\alpha$ in CAF cells may affect the infiltrating macrophages. Using a transwell system of adding macrophage RAW-264.7 cells on the insert wells and seeding CAF.ER $\alpha(+)$ or CAF.ER $\alpha(-)$ cells in the bottom chambers, we found chambers seeded with CAF.ER $\alpha(+)$ had less macrophages infiltrated than with CAF.ER $\alpha(-)$ cells (Fig. 1a). Similar results were obtained when we replaced mouse macrophage RAW-264.7 cells with B6 mouse primary macrophages $(\mathrm{M} \phi)$ (Fig. 1b). We also compared macrophages recruitment between CAF.ER $\alpha(-)$ and CAF.ER $\alpha(+)$ with/without E2 treatment. Our results indicated that E2 treatment can further reduce CAF.ER $\alpha(+)$ diminished macrophage recruitment and treatment with ICI182,780 can reverse E2 and ER $\alpha$ reduced macrophage infiltration (Fig. 1c).

Together, results from Fig. 1 suggest that CAF with $E R \alpha$ expression could reduce macrophage population in the PCa microenvironment.

\section{Infiltrating macrophages enhance PCa invasion}

To further study the consequences of altered infiltrating macrophages on $\mathrm{PCa}$ invasion, we co-cultured mouse CAF.ER $\alpha(+)$ or CAF.ER $\alpha(-)$ cells with mouse macrophages and then collected the conditioned media (CM) to assay the influence on the invasiveness of mouse $\mathrm{PCa}$ cells (TRAMP-C1). As shown in Fig. 2a, the CM from co-culture of CAF.ER $\alpha(+)$ and mouse RAW264.7 cells led a lower TRAMP-C1 cells invasion as compared to CM from co-culture of CAF.ER $\alpha(-)$ and RAW-264.7 cells. Similar results were obtained when we replaced TRAMPC1 cells with human PCa cells CWR22Rv-1 (22Rv1), C4-2, or PC-3 cells (Fig. 2a). Furthermore, replacing mouse macrophage RAW-264.7 cells with B6 primary macrophages $(M \phi)$ also showed similar results (Fig. 2b). 

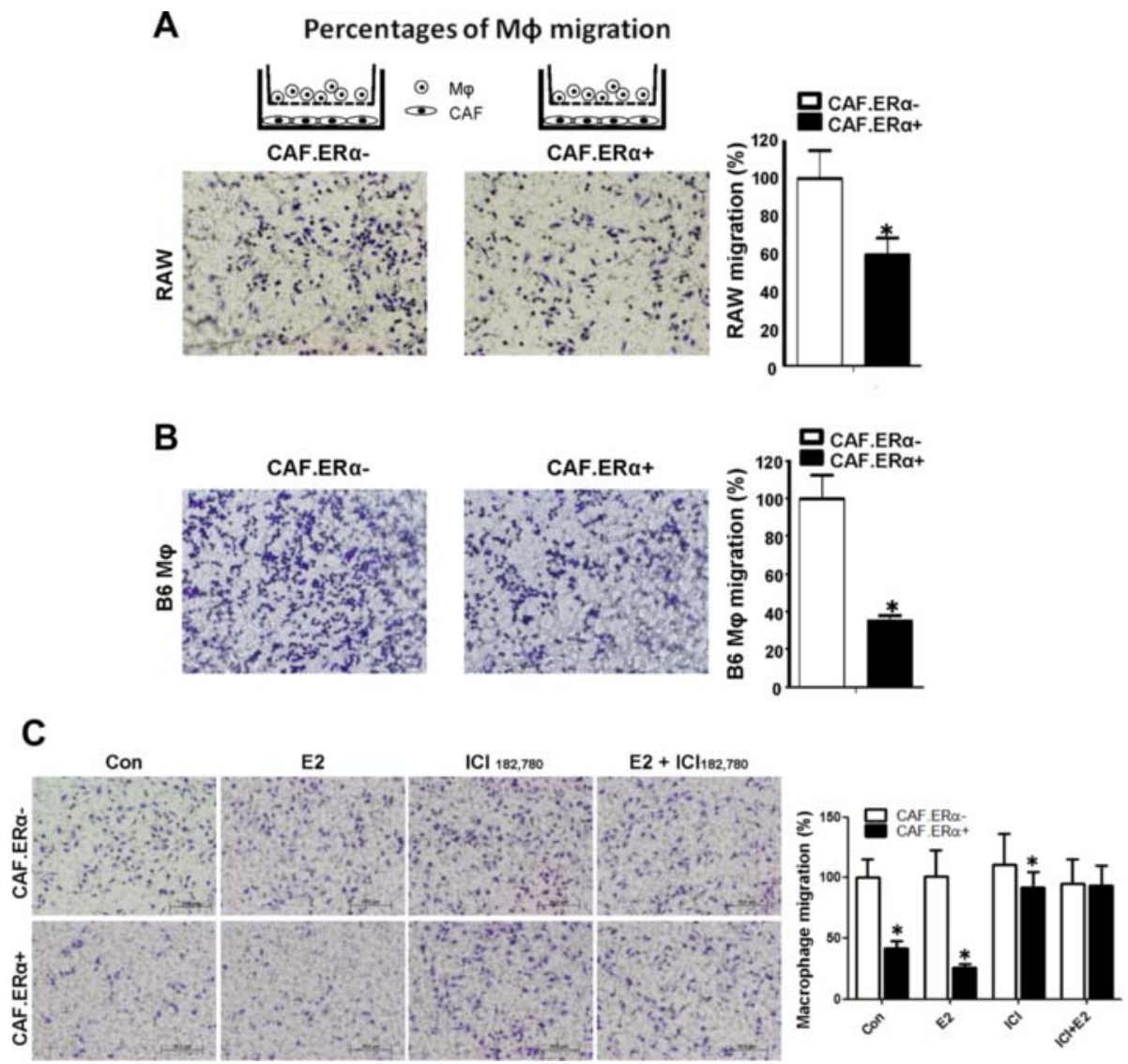

Fig. 1 ERa expression in CAF reduced the macrophage (M ) migration. a and $\mathbf{b}$ CAF ERa reduces the migration of macrophages. CAF.ERa(+) or ERa(-) cells were cultured in 24-well plates for $24 \mathrm{~h}$. We then added macrophages in inserted upper transwells (5 $\mathrm{m}$ pore size) for $24 \mathrm{~h}$ and then compared macrophages migration rate toward CAF.ERa(-) vs. CAF.ERa(+) cells. c 17 -estradiol (E2) treatment can reduce macrophage migration in CAF.ERa(+) cells and ICI182,780 (ICI) treatment can reverse E2 effects. CAF.ERa(-) or CAF.ERa(+) cells were first cultured in media with $5 \%$ CD FBS for 2 days, then seeded in 24-well plates, and incubated with vehicle, E2 $(10 \mathrm{nM})$ or/and ICI (10 M) for $24 \mathrm{~h}$. We then added macrophages into inserted upper transwells $(5 \mathrm{~m}$ pore size) for $24 \mathrm{~h}$ and compared macrophage migration rates toward CAF.ERa(-) vs. CAF.ERa(+). Migrated macrophages were fixed and stained by $1 \%$ toluidine blue in PBS. Quantifications are in right panels. ${ }^{*}, P<0.05$ vs. CAF.ERa(-) cells

We also evaluated ER $\alpha$ activity by E2 and ICI182,780 to confirm stromal ER $\alpha$ role in PCa invasion. We cocultured CAF.ER $\alpha(-) /$ macrophages, CAF.ER $\alpha(+) /$ macrophages with/without ICI182,780 and/or E2 treatment for 2 days. CMs were collected to induce CWR22Rv-1 cells invasion. Our data showed E2 treatment can suppress PCa invasion but adding ICI 182,780 can partially reverse this decreased invasion (Fig. 2c). We also observed similar results in C4-2 cells (Additional file 1: Figure S1).

To mimic the in vivo tumor micro-environment, we applied the 3D invasion assay system to confirm the outcomes from the transwell invasion assay. In the 3D assay, the formation of acini-like structures counts as an indicator for invasion [29]. CM collected from CAF.ER $\alpha(-) /$ macrophages co-culture increased the CWR22Rv-1 cell formation of acini-like structures as compared to $\mathrm{CM}$ from CAF.ER $\alpha(+) /$ macrophages co-culture (Additional file 2: Figure S2A). We also found decreased laminin 5 (an indicator of increased invasion) in PCa cells cultured with the CM from the CAF.ER $\alpha(-) /$ macrophages as compared to CM from CAF.ER $\alpha(+) /$ macrophages (Additional file 2: Figure S2B). Importantly, the expression of the key invasion marker, MMP9, was 2 fold higher in CWR22Rv1 cells treated with CM of CAF.ER $\alpha(-) / R A W 264.7$ co-culture than those treated with CM from CAF.ER $\alpha(+) / R A W 264.7$ co-culture (Additional file 2: Figure S2C) in this 3D invasion system.

Together, results from Fig. 2 and Additional file 2: Figure S2 using different invasion assays with different macrophages and PCa cells all suggested that ER $\alpha$ in CAF could suppress $\mathrm{PCa}$ invasion at least partly via suppressing the infiltrating macrophages.

\section{CAF.ERa(+) suppresses PCa invasion via reduced macrophage infiltration in the in vivo mouse PCa model} To confirm the above in vitro results in the in vivo animal model, we orthotopically co-implanted CAF.ER $\alpha(+)$ or CAF.ER $\alpha(-)$ plus CWR22Rv-1 cells. CWR22Rv1 cells were 

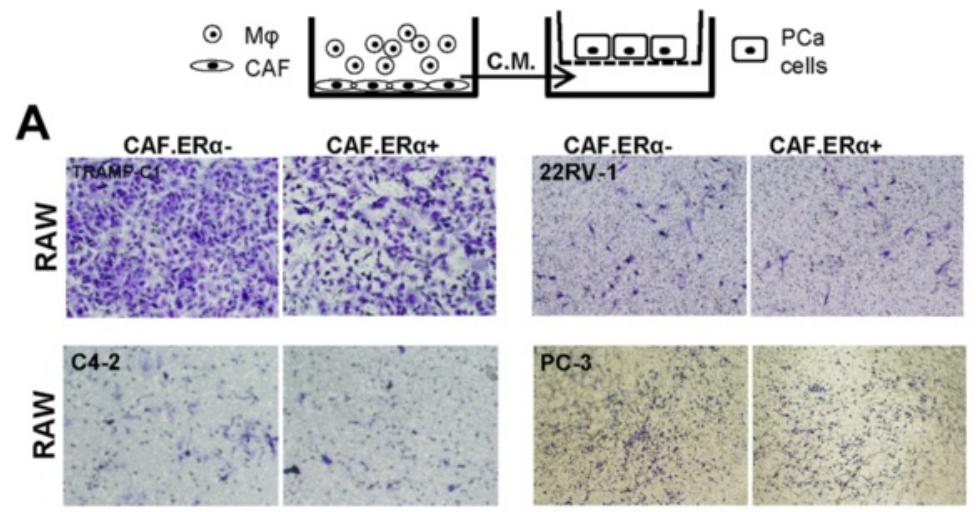

B
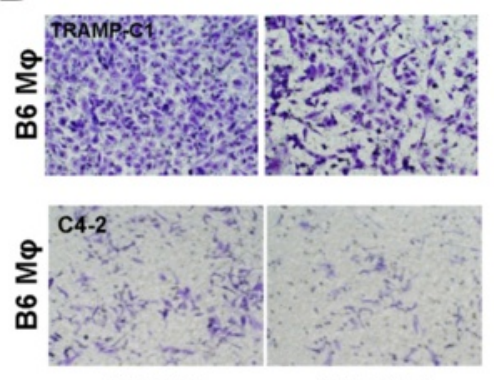

CAF.ERa-
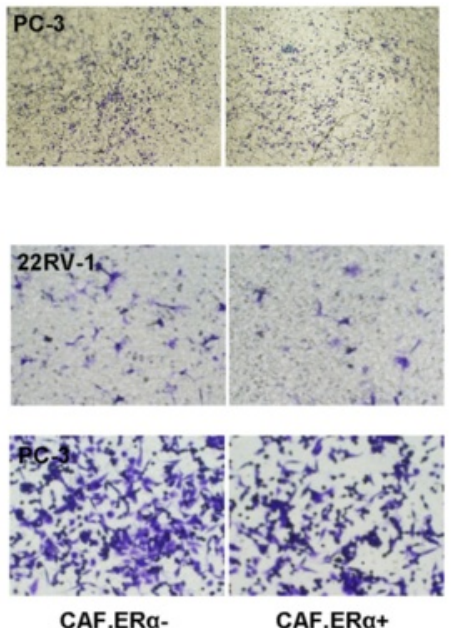

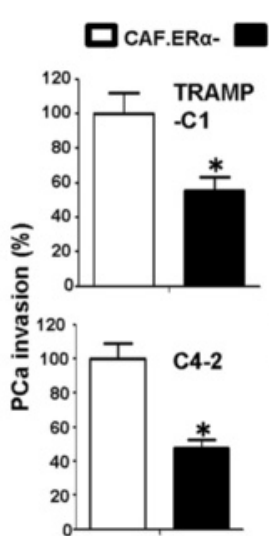

CAF.ER $\alpha+$
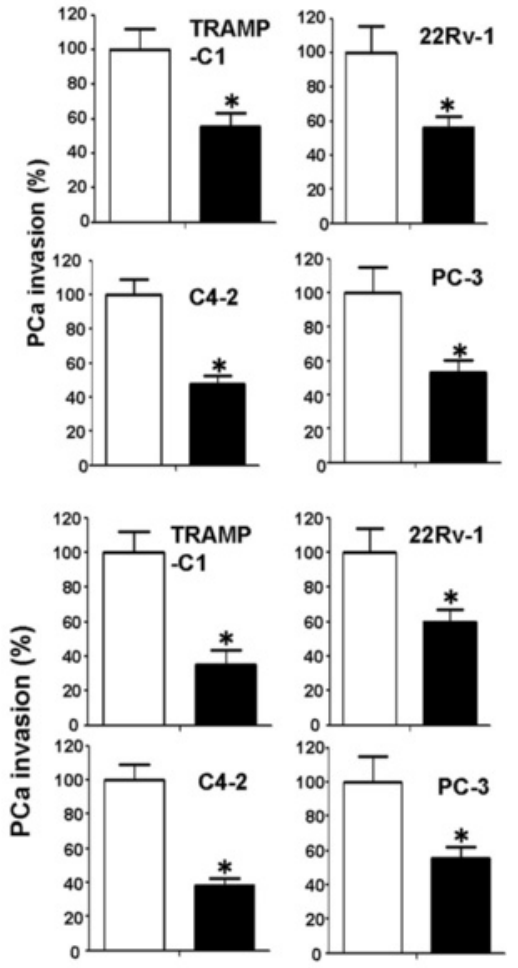
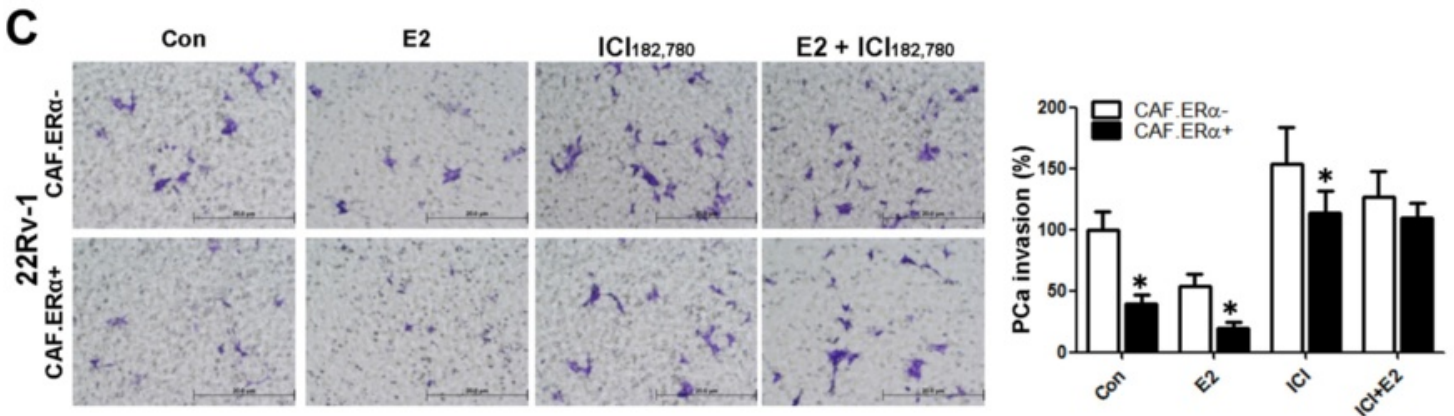

Fig. 2 Effects of CM from co-cultured CAF.ERa(+)/macrophages or CAF.ERa(-)/macrophages (M ) on PCa invasion. The carton illustrates the PCa invasion transwell system. CM was collected from $48 \mathrm{~h}$ co-culture of CAF.ERa(+) or CAF.ERa(-) and RAW264.7 (RAW) cells (a) or B6 primary macrophages (M ) (b), co-cultured CM was added to 24-well plates and the PCa cells TRAMP-C1, CWR22Rv-1 (22Rv1), C4-2, or PC-3, were seeded into inserted transwells pre-coated with matrigel. After 24 to $48 \mathrm{~h}$ incubation (TRAMPC-1 and PC-3 for $24 \mathrm{~h}$; CWR22Rv-1 and C4-2 for 48 h), invaded PCa cells were counted and compared between CM of CAF.ERa(-)/macrophages and CAF.ERa(+)/macrophages. c Estrogen treatment further triggers CAF.ERa(+) reduced PCa invasion. CAF.ERa(-) or ERa(+) cells were treated with vehicle, E2 (10 nM) or/and ICl $\left(\begin{array}{ll}10 & \text { M) }\end{array}\right)$ and co-cultured with macrophages for $48 \mathrm{~h}$. CMs were collected and added to 24-well plates and the PCa cells (CWR22Rv-1) were seeded onto inserted transwells pre-coated with matrigel. After $48 \mathrm{~h}$ incubation, invaded PCa cells were counted and compared, and quantitation data is shown at right. ${ }^{*}, P<0.05$ vs. CAF.ERa $(-) /$ macrophages CM treatment group

stably transfected with firefly luciferase (22Rv1-Luc) to monitor tumor implantation, growth, and metastasis using the non-invasive in vivo IVIS imaging system. Twelve weeks after implantation, tumors were collected from both primary and metastatic sites (Fig. 3). We compared the infiltrated macrophages by IHC staining and found less infiltrated macrophages, including M1 (F4/80) and M2 (CD206) macrophages [30], in CAF.ER $\alpha(+) / 22 R v 1-L u c$ primary tumors than in the CAF.ER $\alpha(-) / 22 R v 1-L u c$ primary tumors (Fig. 3a). We carefully examined the tumor histology, and found that in the co-implants of CAF.ER $\alpha(-)$ and PCa cells, our data show tumors were big, cells were more dense, and necrosis could be observed in the central part of tumor (data not shown). We also found that 4 out of 7 CAF.ER $\alpha(-) / 22 R v-1$-Luc co-implanted mice and 2 out of 7 CAF.ER $\alpha(+) / 22 R v-1$-Luc co-implanted mice with 


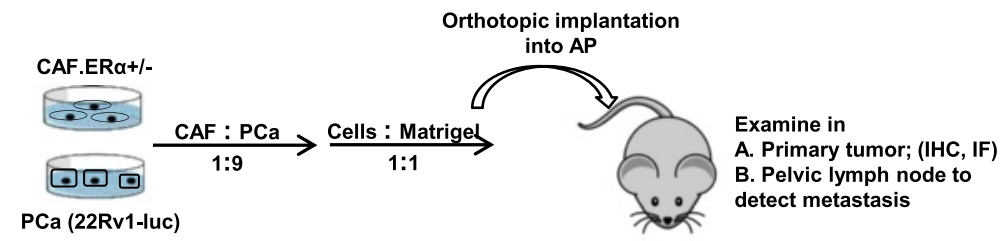

A

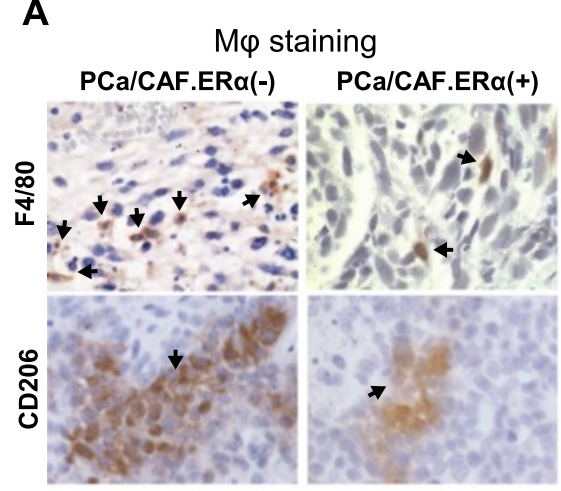

B

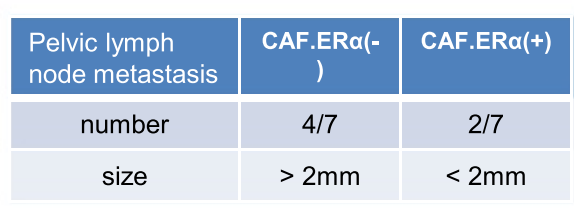

Pelvic lymph node

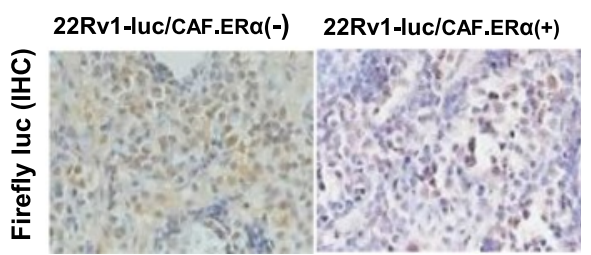

Fig. 3 In vivo tumor model demonstrated CAF ERa reduced macrophages infiltration and PCa cell invasion. Nude mice were orthotopically implanted with CAF.ERa(+) or CAF.ERa(-) mixed with CWR22Rv1 cells that were stably transfected with firefly luciferase (22Rv1-Luc). a Tumors were collected 12 weeks after implantation, and macrophage infiltration was examined by IHC staining of F4/80 (M1 macrophage, upper panel) and CD206 (M2 macrophage, lower panel) [30]. b Pelvic lymph nodes were collected from CAF.ERa(-)/22Rv1-Luc and CAF.ERa(+)/22Rv1-Luc co-cultured groups to determine metastasis by measuring sizes of lymph nodes. We confirmed, by IHC staining of luciferase, the presence of 22Rv1-Luc cells in the lymph nodes (lower panel). There were seven mice in each group. We defined pelvic lymph nodes as metastatic when the diameter was over $2 \mathrm{~mm}$ (upper panel) *, $P<0.05$ vs. CAF.ERa(-)/22Rv1-Luc tumors

enlarged pelvic lymph nodes, but the numbers of enlarged pelvic lymph nodes were variable in individual mice. Among those mice positive for enlarged lymph nodes, the CAF.ER $\alpha(-)$ implanted mice presented larger pelvic lymph nodes than the CAF.ER $\alpha(+)$ implanted group. The length or width of nodes in CAF.ER $\alpha(-)$ mice were $\geq 2 \mathrm{~mm}$, but not in those CAF.ER $\alpha(+)$ implanted group. Thus, we used $2 \mathrm{~mm}$ width or length to define the malignancy of this metastatic PCa. To verify the enlarged pelvic lymph nodes were correlated to metastasis, but not inflammation, the pelvic lymph nodes were IHC stained for presence of luciferase. Importantly, this luciferase staining found fewer metastatic tumors in pelvic lymph nodes in mice coimplanted with CAF.ER $\alpha(+) / 22$ Rv1.Luc cells (Fig. 3b).

Together, results from Fig. 3 suggest that CAF.ER $\alpha(+)$ may suppress $\mathrm{PCa}$ invasion at least partly via altering the macrophage infiltration into $\mathrm{PCa}$ in the in vivo mouse model.

\section{Mechanism dissection how CAF ERa(+) suppresses macrophage infiltration}

To dissect the molecular mechanism(s) by which CAF.ER $\alpha(+)$ expression could suppress macrophage infiltration, we performed Q-PCR gene expression assays with several macrophage migration-related chemokines and cytokines, including the family of the $\mathrm{C}$ - $\mathrm{C}$ motif chemokine ligand (CCL) and interleukin (IL) genes. Our results showed that CCL5 and IL6 gene expression were significantly decreased in CAF.ER $\alpha(+)$ cells as compared to those found in CAF.ER $\alpha(-)$ cells (Fig. 4a). We also co-cultured macrophages with CAFs to study whether macrophages can impact ER $\alpha$ functions in CAF cells. The results showed that compared to CAFs alone, the co-culture of macrophages with CAFs resulted in increased CCL5 and IL6 expression in CAF cells. Consistently, higher ER $\alpha$ expression in CAF decreased CCL5 and IL6 in CAF cells while comparing CAF.ER $\alpha(+) /$ macrophages vs. CAF.ER $\alpha(-) /$ macrophages group (Additional file 3: Figure S3). The IL6 neutralizing antibody did not affect the CAF regulated macrophage migration/infiltration (data not shown). To further confirm CCL5 expression was altered at the protein level, we assayed CCL5 concentration in culture media using ELISA, and results indicated that secreted CCL5 protein decreased in CAF.ER $\alpha(+)$ media (Fig. 4b).

There are two identified transcription factor binding sites in the CCL5 promoter region, including binding sites for NF-kB (-70 to -58$)$ and ( -55 to -42$)$, and a SP1/KLF binding site $(-70$ to -58$)$. Previous studies showed that through a non-ERE pathway the ER $\alpha$ could regulate downstream genes activities, including NF- $\mathrm{kB}$ and AP-1 


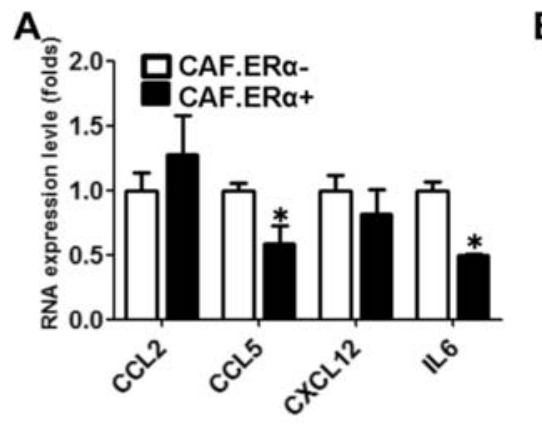

D

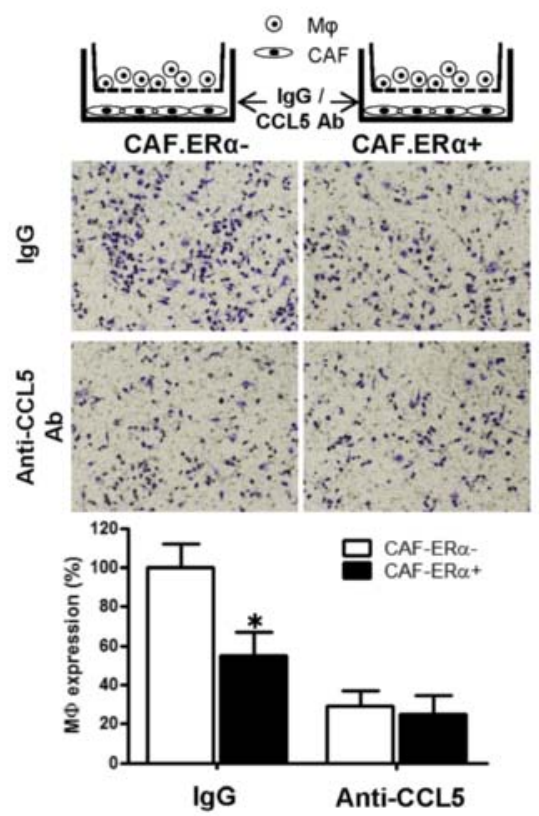

$\mathbf{F}$

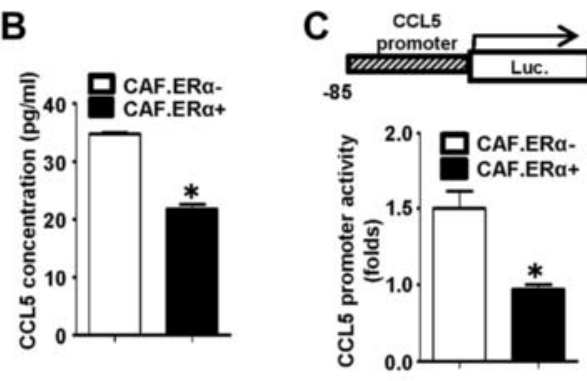

E

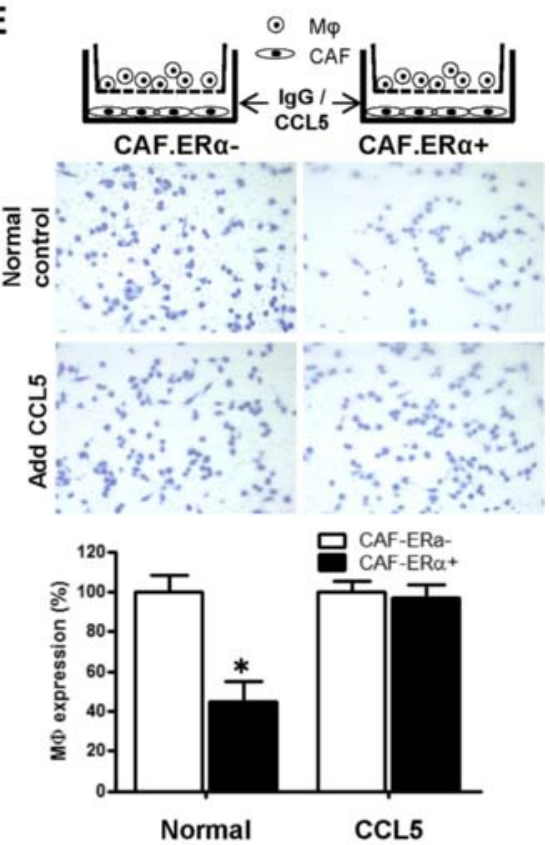

Xenograft mouse PCa

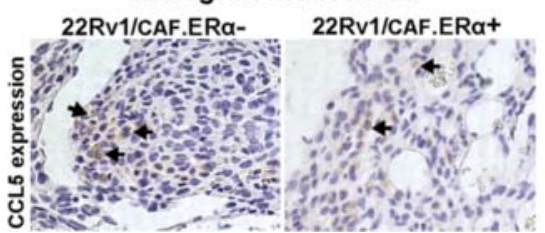

Fig. 4 ERa reduced the CCL5 expression in CAF cells and consequently decreased macrophages infiltration. a We compared gene profiles of macrophage attraction related chemokines/cytokines between CAF.ERa(+) and CAF.ERa(-) by QPCR. $\mathbf{b}$ The comparison of CCL5 production from CAF.ERa(+) and CAF.ERa(-) was determined by ELISA through measuring CCL5 concentration in the CM. c CCL5 promoter luciferase activity was used to determine whether ERa regulates CCL5 expression. CCL5 promoter (-83 bp)-luciferase reporter was transfected into CAF.ERa(+) and CAF.ERa(-) and cultured in CD-FBS media. $10 \mathrm{nM}$ E2 was added and CCL5 promoter luciferase activity was analyzed using a dual luciferase kit. $\mathbf{d}$ CAF were cultured in bottom wells and incubated with CCL5 neutralizing Ab or lgG (control). After $24 \mathrm{~h}$, macrophages were added into inserted upper transwells that also contained CCL5 neutralizing Ab or IgG (control). Migrated macrophages were counted and compared to CAF.ERa(-) with lgG as control. Quantification is in lower panel. e Adding recombinant CCL5 protein reversed CAF.ER(+) reduced macrophage migration. CAF cells were incubated with recombinant CCL5 protein or control for $24 \mathrm{~h}$, and then macrophages with recombinant CCL5 protein or control were added to the inserted transwells for migration assay. All migrated macrophages were compared to CAF.ERa(-) with control protein. Quantification is in lower panel. $\mathbf{f C C L} 5$ expression was confirmed by IHC staining in the in vivo mouse PCa tumors co-implanted with/without both CAF/22Rv1-Luc cells. Arrows show positive CCL5 staining. *, $P<0.05$ vs. CAF.ERa(-)/22Rv1 tumors

$[31,32]$. We therefore focused on examining whether ER $\alpha$ could modulate the CCL5 at the transcriptional level by characterizing the CCL5 promoter (-83 bp) that was constructed into a luciferase reporter [33]. Our results showed that CCL5 luciferase activity is higher in CAF.ER $\alpha(-)$ than in CAF.ER $\alpha(+)$ cells (Fig. 4c).

We also applied an interruption approach to test if interrupting the CCL5 signal with CCL5 neutralizing 
antibody may block the effects of CAF.ER $\alpha(-)$ on macrophages infiltration in the co-culture system. Our results showed the CCL5 neutralizing antibody could significantly and effectively diminish the CAF.ER $\alpha(-)$ modulated macrophage infiltration toward CAF with less effect on CAF.ER(+) modulated infiltration (Fig. 4d, quantification in lower panel).

Then, we applied another interruption approach via adding CCL5 recombinant protein to examine whether the ectopic CCL5 could restore/reverse the CAF.ER $\alpha(+)$ cells' low-capacity to recruit macrophages. Indeed, our results showed adding CCL5 protein could increase the low-capability of CAF.ER $\alpha(+)$ cells to attract macrophages, indicating the lower CCL5 is a key factor that leads to lower macrophages attraction of CAF.ER $\alpha(+)$ (Fig. 4e). We then examined the CCL5 expression in mice with in vivo co-implanted CWR22Rv1-Luc cells with CAF with or without ER $\alpha$

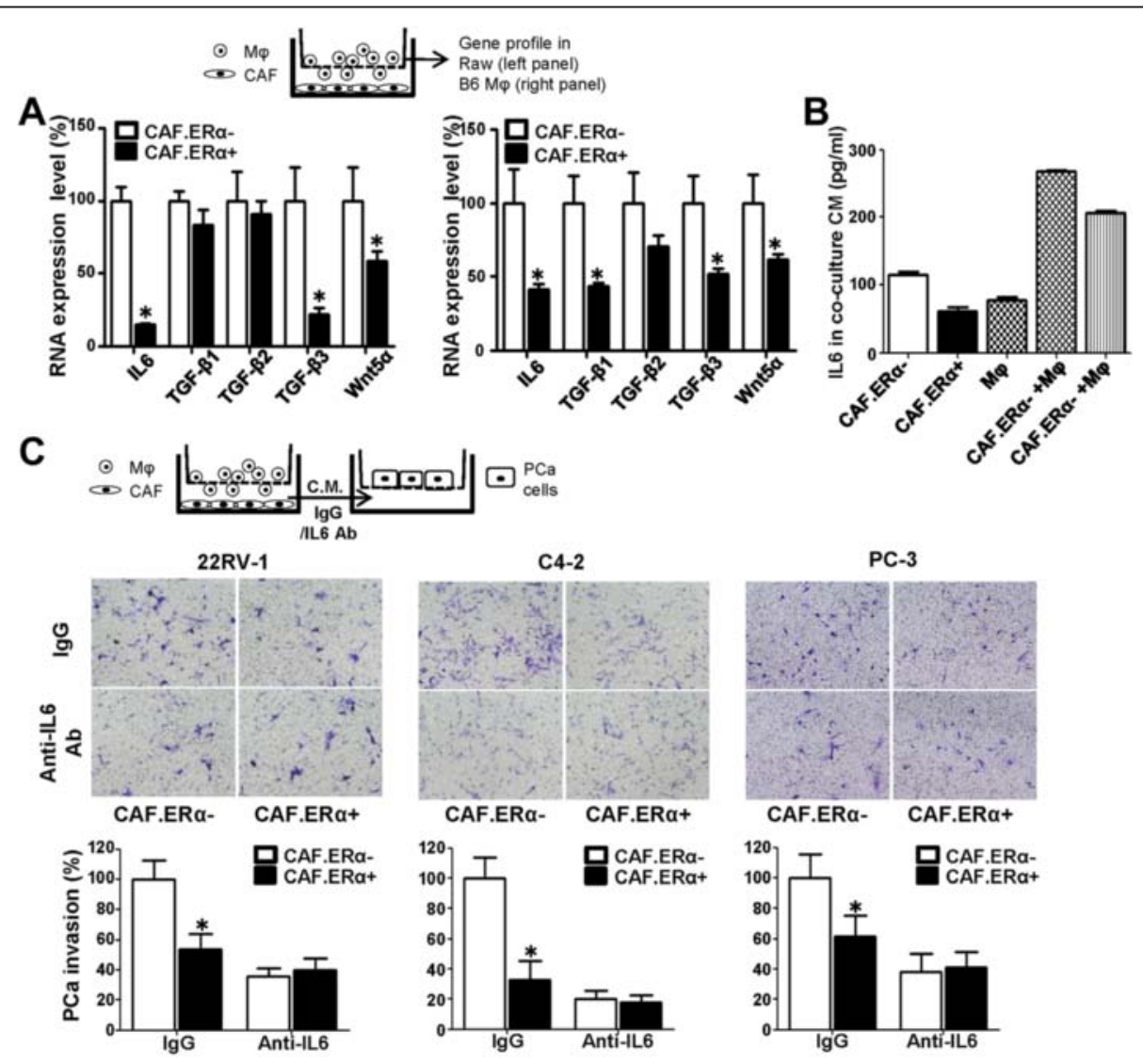

D Xenograft mouse PCa

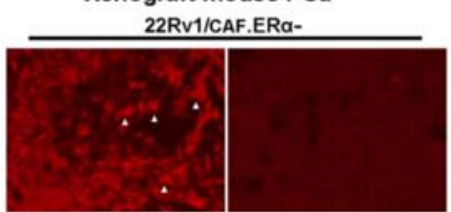

IF: $\quad$ IL-6

$E R \alpha$

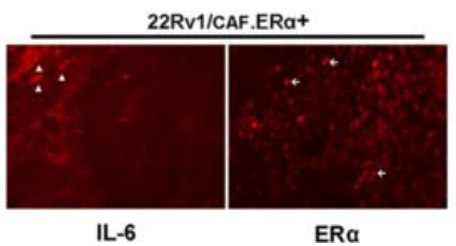

Fig. 5 CAF.ERa(+) CM treated macrophages have a reduced capability of producing IL6, which could consequently reduce PCa invasion. a We compared metastatic-related gene profile expressions by QPCR in macrophages after co-culture with CAF.ERa(+) or CAF.ERa(-) cells. Macrophages were seeded in bottom wells, then CAF.ERa(+) or CAF.ERa $(-)$ cells were seeded onto inserted transwells $(0.4 \mathrm{~m})$ and co-cultured for $24 \mathrm{~h}$. Macrophage RNA was collected and converted to cDNA. Selected metastatic related genes expressions in macrophage were measured by QPCR, RAW cells in left panel and $\mathrm{M}$ in right panel. $\mathbf{b}$ IL6 concentration in CM from CAF/macrophage co-inoculation was measured by ELISA. c IL6 neutralizing antibody blocks macrophages promoted PCa invasion. The next experiment compared macrophages that were incubated with CM either from CAF.ERa(+) or CAF.ERa(-). PCa cells (CWR22Rv1, C4-2, or PC3) were seeded onto matrigel pre-coated transwells for $48 \mathrm{~h}$ to demonstrate invasive ability. $\mathbf{d}$ There is a lower IL6 staining in CAF.ERa(+)/CWR22Rv1 co-implanted tumors. Arrowheads show the cells that express IL6 protein. Arrows indicate cells positive for the ERa expression. IL6 expression is reversely correlative to CAF ERa expression using IF staining. ${ }^{*}, P<0.05$ vs. CAF.ERa-/ 22 Rv1 tumors 
(PCa:CAF $=9: 1$ ) and IHC staining of CCL5 data showed less CCL5 positive signals in CAF.ER $\alpha(+)$ than in CAF.ER $\alpha(-)$ implanted group (Fig. 4f).

Together, results from Fig. 4a-f suggest that CAF.ER $\alpha(+)$ cells have a lower ability to attract macrophages due to a lower chemokine CCL5 expression.

\section{Mechanisms of CAF.ERa + suppressed PCa invasion}

Next, we examined the molecular mechanism(s) by which the CAF.ER $\alpha(+)$ affected macrophages could influence PCa cell invasion. As shown in Fig. 5a, we compared gene profiles of both RAW-264.7 and B6 primary macrophages co-cultured with CAF.ER $\alpha(+)$ or CAF.ER $\alpha(-)$ cells, and found lower IL6 expression in both types of macrophages after co-culture with CAF.ER $\alpha(+)$ cells. Although TGF- $\beta 3$ and Wnt $5 \alpha$ expressions increase, yet their mRNA amounts and expression levels are not as high as IL6. We therefore set the priority to focus on studying IL6. We further examined the altered IL6 expression at the protein level via ELISA assay and data showed there is less IL6 in the CM from CAF.ER $\alpha(+) /$ macrophages co-culture system. This indicates that CAF.ER $\alpha(+)$ cells have less capability to stimulate IL-6 secretion from macrophage RAW-264.7 cells (Fig. 5b). As expected, adding IL6 neutralizing antibody into the $\mathrm{CM}$ diminished the CAF.ER $\alpha(-) /$ macrophage mediated $\mathrm{PCa}$ invasion of CWR22Rv-1, C4-2 and PC3 cells (Fig. 5c). We further demonstrated CAF.ER $\alpha$ signals-mediated CAF IL- 6 reduction could also impact $\mathrm{PCa}$ invasion. We put $\mathrm{CM}$ that was collected from CAF.ER $\alpha(-)$ or CAF.ER $\alpha(+)$ cells with neutralizing IL6 antibody or IgG (control) into bottom wells, and seeded CWR22Rv1 or C4-2 cells into matrigel-coated transwell for invasion assay. Our results showed that IL6 neutralizing antibody can decrease CAF-induced PCa cell invasion (Additional file 4: Figure S4). In vivo evidence from orthotopically xenografted mouse PCa also confirmed the above in vitro data showing CAF.ER $\alpha(+) / 22 R v-1$ tumors have less IL6 expression (Fig. 5d). We also confirmed
IL6 and ER $\alpha$ correlation by IF staining of serial section slides. Our results further indicated there was little IL-6 positive signal when stromal ER $\alpha$ is positively expressed.

Together, results from Fig. 5a-d and Additional file 4: Figure S4 suggest that CAF.ER $\alpha(+)$ may be able to lower the production of IL6 in macrophages, consequently reduce the macrophages-mediated PCa cell invasion.

\section{Correlative expression of ERa, M2 macrophage, CCL5 and IL6 in human prostate tumor}

To confirm our findings in human prostate tumors, we further examined the ER $\alpha$, CD206, CCL5 and IL6 expressions in 14 human PCa tissue specimens by IHC staining. Our results showed a positive correlation between ER $\alpha$, M2 macrophages, CCL5 and IL-6. In high stromal ER $\alpha$ expression samples, the expression levels of CD206 (M2 macrophage marker), CCL5 and IL6 were higher than in samples with low stromal ER $\alpha$ expression (Fig. 6). These results are consistent with our in vitro and in vivo studies.

\section{Discussion}

In the TME, chronic inflammation has been proven to promote cancer progression [34]. Tumor cells can secrete chemokines, cytokines and prostaglandins for inflammatory cells recruitment in order to sustain the inflammatory response. Nelson et al. [35] indicated that inflammation plays an important role in the development and progression of PCa. The chronic inflammation mainly occurred in the area directly adjacent to PCa lesions and induced inflammatory cell infiltration/accumulation. After immune cells accumulated at the sites, the tumor consequently increased prostate epithelial cells proliferation by inflammatory oxidants secretion [36]. Furthermore, cancer related inflammation may affect tumor cell migration, invasion, angiogenesis, etc. Not only epithelial cells, but also CAF can produce inflammatory factors and affect immune cells recruitment. Among several chemokines, CCL1, $-2,-4,-5,-7,-8,-12,-13$, and IL6 might

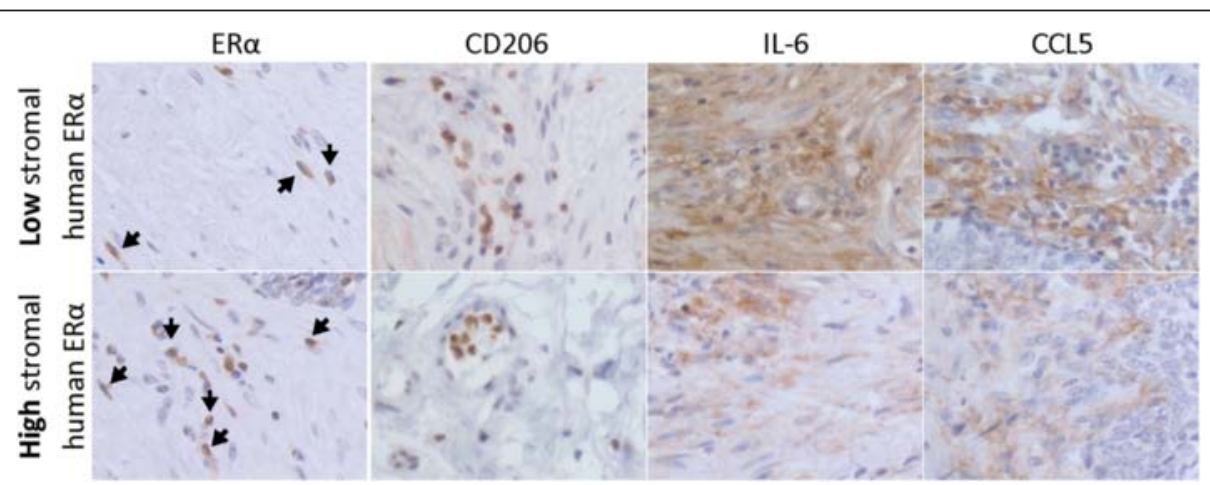

Fig. 6 M2 macrophages, CCL5 and IL6 expression increase in prostate cancer patients with high stromal ERa expression. To confirm our findings in human prostate tumors, we also examined ERa, CD206 (M2 macrophage marker), CCL5 and IL6 in human samples by IHC staining. Samples were provides by Department of Pathology, University of Rochester Medical center 
influence the interaction of inflammation with cancer malignancy, and CCL2, $-3,-5,-7$, CXCL12, -14 , and IL6 were found to be able to affect the macrophage infiltration [37]. In our study, we found that expression of ER $\alpha$ in CAF can reduce the number of infiltrated macrophages recruited by CAF and PCa cells and subsequently suppress cancer invasion.

In the cancer initiation stage, epithelial cancer cells can activate and differentiate fibroblasts into myofibroblasts and the activated fibroblasts consequently promote tumor growth $[38,39]$. When tumors progress, the ratio of cancer cells to CAFs may vary depending on the stages of the disease. A previous study showed that epithelial and CAF cells were set at different ratios to study the interaction between fibroblasts and different breast cancer cells [40]. In a prostate cancer study, Camps et al. co-injected PC-3 cells with CAFs (PCa:CAF $=10: 1 ; 1 \times$ $10^{6}: 1 \times 10^{5}$ ) into mice and successfully promoted tumor growth [41]. In another of our studies, we co-injected CWR22Rv-1 cells and CAFs (22Rv-1:CAFs $=9: 1 ; 9 \times$ $10^{5}: 1 \times 10^{5}$ ) into each lobe of mouse anterior prostates and tested whether the ER $\alpha$ status in CAFs could promote or inhibit tumor invasion [24]. When we changed the PCa:CAF ratio from 9:1 to 5:1, we could also see the similar effects (data not shown). The data presented in this study was collected from $\mathrm{PCa} C \mathrm{CAF}$ at ratio 9:1. In addition to determining the CAF.ER $\alpha$-regulated PCa invasion, in another of our projects studying CAF ER $\alpha$ role in $\mathrm{PCa}$ growth, we found the differential roles of CAF.ER $\alpha(+)$. CAF cells with higher ER $\alpha$ expression could promote the growth, but inhibit the invasion of $\mathrm{PC} 3$, LNCaP, C4-2 and CWR22Rv-1 cells. The in vivo model also demonstrated mice co-injected with CWR22Rv-1 and CAF.ER $\alpha(+)$ cells can develop bigger tumors yet lower metastasis rates as compared to mice co-injected with CWR22Rv-1 and CAF.ER $\alpha(-)$ cells (Da and Yeh et al., paper in preparation).

CAF have been demonstrated to play important roles in cancer progression through promoting tumor initiation, growth and invasion via promotion of the extracellular matrix (ECM) remodeling and release of growth factors and cytokines. CAF are a source of ECMdegrading proteases such as the MMPs [42], which might allow cancer cells to escape the primary tumor site. Our previous study also indicated CAF.ER $\alpha(+)$ suppressed PCa metastasis through decreased Thbs 2 and MMP3 expression [24]. Other studies demonstrated liver CAF could induce metastases through secreting inflammatory factors, like IL6 and MCP-1 [43, 44]. In addition, CAF have the capability to recruit immune cells into the tumor region via altering the expression of IL6, CCL2 [45], or NF-kB signals [13].

Our findings indicated CAF cells expressing ER $\alpha$ have a lower capability to recruit macrophages. Further mechanism dissection showed that both CCL5 and IL6 secretions are decreased in CAF.ER $\alpha(+)$, with CCL 5 subsequently related to macrophage recruitment, but not IL6. We hypothesized that CCL5 may play a key role for recruiting the infiltrating macrophages to $\mathrm{PCa}$ cells. Robinson et al. also demonstrated that CCL5 plays an important role in attracting macrophage migration and may become a target for breast cancer therapy [46]. In a breast cancer murine model, those murine cells treated with Met-CCL5 (receptor antagonist) had a decreased number of infiltrating macrophages associated with a significantly reduced tumor size. The development of "anti-macrophages" may become one option for cancer therapy in the future. M2 type macrophages, one type of inflammatory cells that are differentiated by IL- 4 and IL-13 stimulations, are known as major mediators linking cancer and inflammation [22, 47]. Recent data showed CAF, through stromal-derived growth factor-1 secretion, promote M2-type macrophages expression and PCa progression [48]. We examined M2 macrophages related markers expression in macrophages after CAF CM treatment. Surprising, after co-culture with the CAF.ER $\alpha(+) C M$, the macrophages expressed less M2 macrophage markers, including IL-10, Fuzz1 and Ym1, but not arginase-1 (Additional file 5: Figure S5A), suggesting CAF.ER $\alpha(+)$ may be able to suppress M2-type macrophages in the PCa TME. This conclusion is further supported by the finding of higher IL- 4 and IL-13 expression in CAF.ER $\alpha(-)$ than in CAF.ER $\alpha(+)$ cells (Additional file 5: Figure S5B). This suggests CAF.ER $\alpha(+)$ cells can release less IL-4 and IL-13 and may induce less M2-type macrophages than CAF.ER $\alpha(-)$ cells.

In prostate development, using Cre-loxP gene knockout strategy, reports have shown that ER $\alpha$ plays different roles in prostate epithelial as well as different types of prostate stromal cells [26, 49]. In the PCa mouse models, both ER $\alpha$ knockout [50] and ER $\alpha$ agonist treatment [51] showed mice with activated ER $\alpha$ can develop high-grade PIN, suggesting ER $\alpha$ might play important roles in PCa progression. Early studies indicated the expression of epithelial ER $\alpha$, but not stromal ER $\alpha$, was increased in PCa [52]. Celhay et al. demonstrated stromal ER $\alpha$ may also play an important role in recurrence of hormone refractory PCa. They compared ER $\alpha$ expression by $\mathrm{IHC}$ in 55 paired patient PCa samples collected before androgen deprivation therapy and after hormonal relapse. They found a shorter time to hormonal relapse was associated with low staining for ER $\alpha$ in stromal cells and correlated to shorter patient survival rate [53]. Daniels et al. [28] reported that ER $\alpha$ positive rates reduced in the cancer associated stromal cells compared to the adjacent benign prostate tissue. Although the expression level of ER $\alpha$ in cancer associated stromal cells is relatively weak, the intensity of ER $\alpha$ expression in tumor-associated stroma shows a positive correlation with cancer progression. The reduced CAF ER $\alpha$ IHC staining by Daniels et al. [28] 
supports our finding that CAF ER $\alpha$ plays a protective role in cancer invasion. Furthermore, $\mathrm{PCa}$ patients with CAF.ER $\alpha(+)$ expression have a better PSA free recurrence survival rate [24]. Our data demonstrated stromal ER $\alpha$ can inhibit PCa invasion through suppressing macrophage infiltration into tumor sites and directly decrease cytokine secretion in PCa cells.

Platz et al. indicated chronic inflammation could be an epidemiologic factor for PCa [54], and De Marzo et al. also linked the PCa progression to inflammation related dietary factors [4]. Prins et al. [55] demonstrated that estrogen induced inflammation is specifically mediated by epithelial ER $\alpha$. The epithelial inflammatory cell infiltrates were observed with aging in wild type and ER $\beta$ knock out (ER $\beta K O)$, but not in ER $\alpha \mathrm{KO}$, mice after DES (Diethylstilbestrol) treatment. Van Laere et al. demonstrated that activation of NF$\mathrm{kB}$ in inflammatory breast cancer was associated with loss of ER $\alpha$ expression, suggesting ER $\alpha$ might play a positive role in anti-inflammation [56]. In autoimmune encephalomyelitis, $E R \alpha$-ligands mediated anti-inflammation is important in neuroprotection for reducing the levels of central nervous system inflammation [57]. ER $\alpha$ has been proven to have an anti-inflammatory function in macrophages. However, the ER $\alpha$ roles in inflammation-mediated PCa progression may depend on the ER $\alpha$ location. Our data showed stromal ER $\alpha$ can decrease macrophage infiltration, but may also suppress CAF-mediated inflammation response.

Our results showed ER $\alpha$ in CAF not only decreases IL6 expression in CAF cells, but also regulates macrophages activity to decrease IL6 secretion, although the mechanisms by which CAF.ER $\alpha(+)$ cells affect macrophage activity are still unclear. Previous studies indicated IL6 and leukemia inhibitory factor (LIF) secretion increases in tumor tissues can promote TAM generation. Deprivation of IL6 and LIF can suppress TAM induction. Early studies indicated that inflammatory cytokines, such as IL6, might play major roles in the metastasis of breast and neck cancers $[58,59]$. Michalaki et al. [60] measured serum IL6 concentration from patients and found it is higher in patients with metastatic disease than localized disease. Lou et al. [61] also determined IL6 plays an important role in the PCa metastatic Stat3 signaling transduction pathway. But, after CAF CM treatment, we found IL6 expression in PCa cells shows no significant difference between CAF cells with/without ER $\alpha$. Hsu et al. also found anti-IL6 might suppress the MMP2 and MMP9 expressions in a colon cancer model [62]. Importantly, Karin et al. demonstrated estrogen and propyl pyrazole triol (PPT, ER $\alpha$ specific agonist) could suppress metastasis of hepatocellular carcinoma via inhibition of IL6 expression [63]. They also indicated that the gender difference in tumor susceptibility resulted from a downregulation of IL6 production by macrophages in response to estrogens.

\section{Conclusion}

Current concepts of PCa therapy mainly focus on applying anti-androgens/blocking AR activity. An increasing body of studies indicated targeting AR could suppress PCa growth but promote metastasis. Meanwhile, targeting sex hormones with various therapies may have dramatic effects, but also result in side effects. In this study, our results suggest that CAF ER $\alpha$ could be applied as a

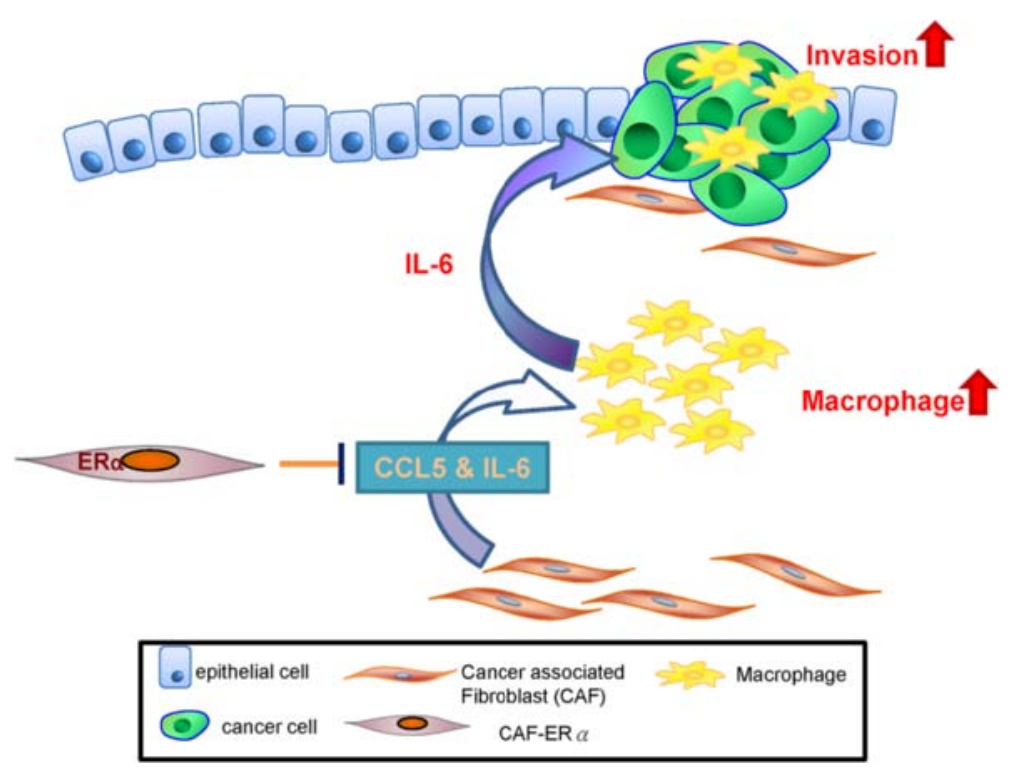

Fig. 7 CAF.ERa(+) decreases prostate cancer invasion via diminishing tumor associated macrophage infiltration and IL6 secretion. Schematic diagram shows that CAF.ERa(+) cells diminishes macrophage recruited toward to PCa via reducing CAF CCL5 secretion. These CAF.ERa(+) cells reduced invasion of PCa cells are at least partly due to reduced IL6 expression in the macrophages and CAFs 
prognostic marker to predict cancer progression, and targeting CCL5 and IL6 may be applied as an alternative therapeutic approach to reduce M2 type macrophage and PCa invasion in CAF.ER $\alpha(-)$ PCa patients (Fig. 7). Our study provides candidates, like CCL5 and macrophages, for cancer therapy. In the future, we can try to block the CCL5 signaling pathway to evaluate the possibility of CCL5 in PCa treatment.

\section{Methods}

\section{Cell lines}

Four PCa cell lines, TRAMP-C1, CWR22Rv-1, C4-2, and $\mathrm{PC}-3$, and the mouse macrophage cell line, RAW264.7, were purchased from the American Type Culture Collection (ATCC, Rockville, MD). CAF were prepared as a primary culture from 36-weeks-old TRAMP mice and immortalized by SV40 large T-antigen using the detailed process described previously [24]. All cells were maintained in RPMI media with 10 \% FBS and $1 \%$ penicillin/ streptomycin.

Isolation and primary culture of macrophages from B6 mice B6 mice were euthanized by $\mathrm{CO}_{2}$ asphyxiation and cervical dislocation. After sterilization, femur bones were isolated and sterilized in $70 \%$ ethanol and rinsed with PBS. We cut the bones at both ends, flushed the bone-marrow out with RPMI media with $10 \%$ heatinactivated FBS using syringes with 25-gauge needles. Bone marrow fluid was centrifuged at $1200 \mathrm{x}$ rpm for 10 mins, and cells were cultured with RPMI media with macrophages colony-stimulating factor (M-CSF $20 \mathrm{ng} / \mathrm{ml}$ ). After 6 days of culture, primary macrophages became mature for experimentation.

\section{Lentiviral ERa transduction of CAF cells and firefly} luciferase transduction of CWR22Rv-1 cells

The ER $\alpha$ cDNA was cloned into PmeI site of pWPI lentiviral vector. The $293 \mathrm{~T}$ packaging cells were transiently transfected with pMD2.G and psPAX2 with pWPIvector or $\mathrm{pWPI-ER} \alpha$, to produce lentiviral particles. The supernatants containing lentiviral particles were collected $48 \mathrm{~h}$ post-transfection of $293 \mathrm{~T}$ cells, and polybrene was added. The lentiviral supernatants were then filtered and used to transduce CAF for $48 \mathrm{~h}$. The viral vector or ER $\alpha$ transduced CAF were then subjected to $5 \mathrm{mg}$ / L blasticidin selection. To monitor tumor progression by In vivo Imaging System (IVIS) system, CWR22Rv-1 cells were tagged with firefly luciferase by lentivirus system.

\section{Migration assay}

CAF.ER $\alpha(+)$ or CAF.ER $\alpha(-)$ were cultured in 24-well plates. After $24 \mathrm{~h}$, macrophages were seeded on the inserted transwells. After $24 \mathrm{~h}$ co-incubation, transwells were washed with PBS and then fixed by $75 \%$ ethanol. Next, transwell membranes were stained with $1 \%$ toluidine blue (w/v, prepared in PBS) and nonmigrated macrophages, remaining on the inner transwell surface, were wiped off. Macrophages that migrated to the bottom side of membranes were counted in ten representative areas via microscope (x100 fold).

\section{Invasion assay}

Conditioned media (CM) collected from the CAF/macrophages co-culture system were used to attract PCa cells invasion via matrigel coated $(0.2 \mathrm{mg} / \mathrm{ml}, 100 \mu \mathrm{l}$, air dried overnight) transwells. For the co-culture system, CAF.ER $\alpha(+)$ or CAF.ER $\alpha(-)$ were seeded in the bottom wells of 6-well plates and macrophages were added into the top transwells (pore size is $0.4 \mu \mathrm{m}$ ). The CM was collected from bottom wells after $48 \mathrm{~h}$ co-culture. Then, CM was added into each well of new 24-well plates, then matrigel coated transwells

Table 1 Sequence of qPCR primers

\begin{tabular}{|c|c|c|}
\hline Name & & Sequence, $5 \rightarrow 3$ \\
\hline \multirow[t]{2}{*}{$\mathrm{CCl} 2$} & sense & TAA AAA CCT GGA TCG GAA CCA AA \\
\hline & antisense & GCA TTA GCT TCA GAT TTA CGG GT \\
\hline \multirow[t]{2}{*}{$\mathrm{CCl} 5$} & sense & TAT CCT GGT GGA GTT GTG \\
\hline & antisense & CAG AGT CAT CCC TGC TTC \\
\hline \multirow[t]{2}{*}{$\mathrm{CxCl}-12$} & sense & TGC ATC AGT GAC GGT AAA CCA \\
\hline & antisense & CAC AGT TTG GAG TGT TGAG GAT \\
\hline \multirow[t]{2}{*}{$1 L 6$} & sense & CTG CAA GAG ACT TCC ATC CAG \\
\hline & antisense & AGT GGT ATA GAC AGG TCT GTT GG \\
\hline \multirow[t]{2}{*}{ MMP1 } & sense & CCC TGG GAA GCT GTT ATC TTC AA \\
\hline & antisense & CGA CCC ACT TCT GAT GGG CT \\
\hline \multirow[t]{2}{*}{ MMP2 } & sense & ACC TGA ACA CTT TCT ATG GCT G \\
\hline & antisense & CTT CCG CAT GGT CTC GAT G \\
\hline \multirow[t]{2}{*}{ MMP9 } & sense & GGA CCC GAA GCG GAC ATT G \\
\hline & antisense & CGT CGT CGA AAT GGG CAT CT \\
\hline \multirow[t]{2}{*}{ MMP13 } & sense & TGT TTG CAG AGC ACT ACT TGA A \\
\hline & antisense & CAG TCA CCT CTAAGCC AAA GAA A \\
\hline \multirow[t]{2}{*}{ Fizzl } & sense & CCA ATC CAG CTA ACT ATC CCT CC \\
\hline & antisense & ACC CAG TAG CAG TCA TCC CA \\
\hline \multirow[t]{2}{*}{ Arginase 1} & sense & TGT CCC TAA TGA CAG CTC CIT \\
\hline & antisense & GCA TCC ACC CAA ATG ACA CAT \\
\hline \multirow[t]{2}{*}{$Y m 1$} & sense & CAG GTC TGG CAA TTC TTC TGA A \\
\hline & antisense & GTC TTG CTC ATG TGT GTA AGT GA \\
\hline \multirow[t]{2}{*}{$1 / 4$} & sense & ATC ATC GGC ATT TTG AAC GAG G \\
\hline & antisense & TGC AGC TCC ATG AGA ACA CTA \\
\hline \multirow[t]{2}{*}{$1 L 13$} & sense & TGA GCA ACA TCA CAC AAG ACC \\
\hline & antisense & GGC CTा GCG GTT ACA GAG G \\
\hline \multirow[t]{2}{*}{ GAPDH } & sense & AAT GTC ACC GTT GTC CAG TTG \\
\hline & antisense & GTG GCT GGG GCT CTA CTT C \\
\hline
\end{tabular}


were inserted and PCa cells (TRAMP-C1, CWR22Rv1, C4-2, or PC-3, as in figures) at $5 \times 10^{4} / 150 \mu \mathrm{l}$ were seeded on each transwell. After $24 \mathrm{~h}$ incubation, transwells were washed, fixed, and stained. The method for counting invaded cell numbers was the same as with migration assay.

\section{Immunohistochemistry (IHC)}

IHC staining was carried out as described previously [64]. Sections were incubated with the primary antibodies, anti-F4/80 (anti-mouse macrophages, Biolegend, San Diego, CA), anti-CD206 (anti-M2 macrophage; sc20150, Santa Cruz, Dallas, TX), anti-CCL5 (Ameritech Biomedicines, Houston, TX), anti-IL6 (Abcam, ab6672, Cambridge, MA) and anti-firefly (Santa Cruz, Dallas, $\mathrm{TX}$ ), in $3 \% \mathrm{BSA}$ in PBS overnight at $4{ }^{\circ} \mathrm{C}$ followed by respective secondary antibodies.

\section{RNA extraction and quantitative real-time $P C R$ analysis}

Total RNA was extracted by Trizol reagent (Invitrogen, Carlsbad, CA) according to the manufacturer's instructions. RNAs $(1 \mu \mathrm{g})$ were subjected to reverse transcription using Superscript III transcriptase (Invitrogen). The obtained cDNAs were applied for qPCR using a SYBR green Bio-Rad CFX96 system. Primers used are listed in Table 1. Gene mRNA expression levels were normalized to the mRNA level of GAPDH.

\section{CCL5 promoter luciferase assay}

CCL5 promoter luciferase activity was performed using Lipofectamin 2000 (Invitrogen). CAF cells were transfected with CCL5-Luc $(0.4 \mu \mathrm{g})$ and $1 \mathrm{ng}$ pRL-TK-Luc reporter gene. After transfection, the media were refreshed to $10 \% \mathrm{charcoal} /$ dextran stripped (CD)-FBS media for $24 \mathrm{~h}$ and $10 \mathrm{nM}$ E2 was added as indicated for an additional $24 \mathrm{~h}$. Cells were then harvested for the dual luciferase assay kit (Promega, Madison, WI).

\section{ELISA}

CM was collected from CAF only or CAF co-cultured with macrophages for ELISA analyses of CCL5 and IL6 (eBioscience, San Diego, CA) according to the manufacturer's instructions.

\section{Orthotopic implantation}

For the orthotopic implantation in mice, CWR22Rv-1 cells were transduced with firefly cDNA (22Rv1-Luc). CAF were mixed with 22Rv1-Luc cells (1:9 ratio) and injected into anterior prostate of 8 weeks old athymic nude mice [24, 41]. For cells injection, 22Rv1-Luc/CAF cells $\left(9: 1\right.$ ratio, total $\left.1 \times 10^{6}\right)$ were suspended in $20 \mu \mathrm{l}$ of media and Matrigel mix (1:1, v:v). Seven animals were used per group. Mice were monitored by IVIS every 2 weeks for tracking tumor growth and metastasis by intraperitoneal injection of luciferin (Gold Biotechnology, St. Louis, MO) to allow the luciferase to fluoresce. Tumors from primary and metastatic sites were collected after a final IVIS imaging at 12 weeks after implantation. Tumor sizes and macrophages infiltration were compared after IHC staining by macrophage markers. Lymph nodes were stained with firefly luciferase antibody (Santa Cruz, c-12) to confirm cancer cells metastasized from the primary tumor sites. All mice experiments were performed under a protocol approved by the Institutional Animal Care and Use Committee (IACUC) of the University of Rochester Medical Center.

\section{Statistical analysis}

Values were expressed as mean \pm standard deviation (S.D.). The Student's $t$ test was used to calculate twosided $P$ values, and considered statistically significant when $P<0.05$.

\section{Additional files}

Additional file 1: Figure S1. Stromal E2/ERa signals negatively-regulate the PCa invasion. CAF.ERa(-) or ERa(+) cells were treated with vehicle, E2 $(10 \mathrm{nM})$ or/and $\mathrm{ICl}_{182,780}(10 \mathrm{M})$ and co-cultured with macrophages for $48 \mathrm{hr}$. CMs were collected and added to 24-well plates and the PCa cells (C4-2) were seeded into inserted transwells pre-coated with matrigel. After $48 \mathrm{hr}$ of incubation, invaded PCa cells were counted and compared, and quantitation data is shown below the images.

Additional file 2: Figure S2. CM from co-cultured CAF/macrophages affects PCa invasion in the 3D culture system. The carton illustrates the experimental system. CM was collected from co-culture of CAF.ERa(+) or CAF.ERa(-) cells and RAW264.7 cells or B6 primary macrophages (M ) for $24 \mathrm{hr}$. The CM was then used to treat CWR22Rv-1 cells for 3 days, then seeded in 3D environment for 12 days to form inter-acinar bridges. (A) Numbers of inter-aciniar bridges were counted per field and quantifications are in right panels. (B) Laminin 5 mRNA was quantified to show the invasive potential of the PCa cells in the 3D culture environment. At Day 12, RNA was extracted from PCa cells and expression levels of laminin 5 were measured by qPCR and quantifications are shown. (C) Expression of invasion related marker, MMP9, was also demonstrated by Q-PCR in CWR22Rv-1 cells pre-inoculated with the collected CM, quantification is shown. ${ }^{*}, \mathrm{P}<0.05$ vs. CM from CAF.ERa(-)/macrophage group.

Additional file 3: Figure S3. Infiltrated Macrophages ( $M$ ) can affect the macrophages recruited-related gene profiles in CAF cells. CAF.ERa(-) or CAF.ERa(+) cells were co-cultured with macrophages for 2 days. We compared gene profiles of macrophages attraction related CCL5 and IL6 in CAF.ERa(+) and CAF.ERa(-) using qPCR.

Additional file 4: Figure S4. Co-culture of CAF ERa(+) cells and PCa cells can decrease PCa cell invasion through changing IL-6 expression. CM was collected from CAF.ERa(-) and CAF.ERa(+) cells together with or without with IL-6 neutralizing antibody (Anti IL-6) or IgG (control) into bottom wells of 24-well transwell systems. We then trypsinized and seeded CWR22Rv-1 and C4-2 cells $\left(1 \times 10^{5}\right)$ into matrigel-pre-coated transwells for invasion assay. Quantitation is at right.

Additional file 5: Figure S5. CAF.ERa(+) can reduce the M2 marker expressions in the co-cultured macrophages (M ). (A) ERa in CAF cells inhibits M2-type macrophages transformation. (B) mRNA expressions of IL-4 and IL-13 in CAF cells were assayed by qPCR. mRNA expressions of M2 markers in macrophages were assayed by qPCR. After incubating with CM collected from CAF.ERa(+) or CAFERa(-), macrophages were collected to detect M2 markers by $\mathrm{qPCR}$. ${ }^{*}, \mathrm{P}<0.05$ vs. CAF.ERa(-) cells; $\S, \mathrm{P}<0.05$ vs. $\mathrm{M} ; \quad, \mathrm{p}<0.05$ vs. M /CAF.ERa(-) CM. 


\section{Abbreviations}

CAF: cancer associated fibroblasts; M : macrophages; TAM: tumor associated macrophages; EMT: epithelial to mesenchymal transition; TME: tumor microenvironment.

\section{Competing interests}

The authors confirm that there are no conflicts of interest.

\section{Authors' contributions}

CR Yeh and SY Yeh developed the original hypothesis, experimental design and draft of manuscript. CR Yeh carried out in vitro studies, especially macrophage recruitment and PCa invasion. CR Yeh, S Slavin and J Da carried out animal studies. I Hsu prepared plasmid constructions. FJ Chou and J Ding worked on data collecting and paper revision. GQ Xiao preformed immunochemical staining. J Luo carried out in vitro studies especially the IL6 and CCL5 neutralizing antibody study. All authors read and approved the final manuscript.

\section{Acknowledgments}

We thank Dr. Peter J. Nelson (Munich, Germany) for providing CCL5 promoter luciferase plasmid, and Karen Wolf for assistance in manuscript preparation. This work was partly supported by NIH Grant CA137474 and China 973 Grant 2012CB518304.

\section{Author details}

${ }^{1}$ George Whipple Lab for Cancer Research, Departments of Urology and Pathology, University of Rochester Medical Center, Rochester, NY 14642, USA. ${ }^{2}$ Department of Pathology, University of Rochester Medical Center, Rochester, NY 14642, USA.

Received: 6 April 2015 Accepted: 16 December 2015 $\mathrm{BP}$.

\section{References}

1. Siegel R, Naishadham D, Jemal A. Cancer statistics, 2013. CA Cancer J Clin. 2013;63:11-30

2. Nunez C, Cansino JR, Bethencourt F, Perez-Utrilla M, Fraile B, MartinezOnsurbe $P$, et al. TNF/IL-1/NIK/NF-kappa B transduction pathway: a comparative study in normal and pathological human prostate (benign hyperplasia and carcinoma). Histopathology. 2008;53:166-76.

3. Nelson WG, De Marzo AM, DeWeese TL, Isaacs WB. The role of inflammation in the pathogenesis of prostate cancer. J Urol. 2004;172:S6-11. discussion S11-12.

4. De Marzo AM, Platz EA, Sutcliffe S, Xu J, Gronberg H, Drake CG, et al Inflammation in prostate carcinogenesis. Nat Rev Cancer. 2007;7:256-69.

5. Sciarra A, Di Silverio F, Salciccia S, Autran Gomez AM, Gentilucci A, Gentile V. Inflammation and chronic prostatic diseases: evidence for a link? Eur Urol. 2007;52:964-72.

6. MacLennan GT, Eisenberg R, Fleshman RL, Taylor JM, Fu P, Resnick MI, et al. The influence of chronic inflammation in prostatic carcinogenesis: a 5-year followup study. J Urol. 2006;176:1012-6.

7. Bingle L, Brown NJ, Lewis CE. The role of tumour-associated macrophages in tumour progression: implications for new anticancer therapies. J Pathol. 2002;196:254-65

8. Lewis CE, Pollard JW. Distinct role of macrophages in different tumor microenvironments. Cancer Res. 2006;66:605-12.

9. Kalluri R. Basement membranes: structure, assembly and role in tumour angiogenesis. Nat Rev Cancer. 2003;3:422-33.

10. Kojima Y, Acar A, Eaton EN, Mellody KT, Scheel C, Ben-Porath I, et al. Autocrine TGF-beta and stromal cell-derived factor-1 (SDF-1) signaling drives the evolution of tumor-promoting mammary stromal myofibroblasts. Proc Natl Acad Sci U S A. 2010;107:20009-14.

11. Quante M, Tu SP, Tomita H, Gonda T, Wang SS, Takashi S, et al. Bone marrow-derived myofibroblasts contribute to the mesenchymal stem cell niche and promote tumor growth. Cancer Cell. 2011;19:257-72.

12. Tomasek JJ, Gabbiani G, Hinz B, Chaponnier C, Brown RA. Myofibroblasts and mechano-regulation of connective tissue remodelling. Nat Rev Mol Cell Biol. 2002:3:349-63.

13. Erez N, Truitt M, Olson P, Arron ST, Hanahan D. Cancer-Associated Fibroblasts Are Activated in Incipient Neoplasia to Orchestrate Tumor-Promoting Inflammation in an NF-kappaB-Dependent Manner. Cancer Cell. 2010;17:135-47.
14. Ellem SJ, Schmitt JF, Pedersen JS, Frydenberg M, Risbridger GP. Local aromatase expression in human prostate is altered in malignancy. J Clin Endocrinol Metab. 2004:89:2434-41.

15. Vermeulen A, Kaufman JM, Goemaere S, van Pottelberg I. Estradiol in elderly men. Aging Male. 2002;5:98-102.

16. Bosland MC, Ford $\mathrm{H}$, Horton L. Induction at high incidence of ductal prostate adenocarcinomas in NBL/Cr and Sprague-Dawley Hsd:SD rats treated with a combination of testosterone and estradiol-17 beta or diethylstilbestrol. Carcinogenesis. 1995;16:1311-7.

17. Nilsson S, Gustafsson JA. Estrogen receptor transcription and transactivation: Basic aspects of estrogen action. Breast Cancer Res. 2000;2:360-6.

18. Greene GL, Gilna P, Waterfield M, Baker A, Hort Y, Shine J. Sequence and expression of human estrogen receptor complementary DNA. Science. 1986;231:1150-4.

19. Kuiper GG, Enmark E, Pelto-Huikko M, Nilsson S, Gustafsson JA. Cloning of a novel receptor expressed in rat prostate and ovary. Proc Natl Acad Sci U S A. 1996:93:5925-30.

20. Leav I, Lau KM, Adams JY, McNeal JE, Taplin ME, Wang J, et al. Comparative studies of the estrogen receptors beta and alpha and the androgen receptor in normal human prostate glands, dysplasia, and in primary and metastatic carcinoma. Am J Pathol. 2001;159:79-92.

21. Mantovani A, Allavena P, Sica A, Balkwill F. Cancer-related inflammation. Nature. 2008:454:436-44

22. Solinas G, Germano G, Mantovani A, Allavena P. Tumor-associated macrophages (TAM) as major players of the cancer-related inflammation. J Leukoc Biol. 2009;86:1065-73.

23. Mantovani A, Sozzani S, Locati M, Allavena P, Sica A. Macrophage polarization: tumor-associated macrophages as a paradigm for polarized M2 mononuclear phagocytes. Trends Immunol. 2002;23:549-55.

24. Slavin S, Yeh CR, Da J, Yu S, Miyamoto H, Messing EM, et al. Estrogen receptor alpha in cancer-associated fibroblasts suppresses prostate cancer invasion via modulation of thrombospondin 2 and matrix metalloproteinase 3. Carcinogenesis. 2014;35:1301-9.

25. Chen M, Yeh CR, Shyr CR, Lin HH, Da J, Yeh S. Reduced prostate branching morphogenesis in stromal fibroblast, but not in epithelial, estrogen receptor alpha knockout mice. Asian J Androl. 2012;14:546-55.

26. Vitkus S, Yeh CR, Lin HH, Hsu I, Yu J, Chen M, et al. Distinct function of estrogen receptor alpha in smooth muscle and fibroblast cells in prostate development. Mol Endocrinol. 2013;27:38-49.

27. Bosland MC. Sex steroids and prostate carcinogenesis: integrated, multifactorial working hypothesis. Ann N Y Acad Sci. 2006;1089:168-76.

28. Daniels G, Gellert LL, Melamed J, Hatcher D, Li Y, Wei J, et al. Decreased expression of stromal estrogen receptor alpha and beta in prostate cancer. Am J Transl Res. 2014;6:140-6.

29. Xiang B, Muthuswamy SK: Using Three Dimensional Acinar Structures for Molecular and Cell Biological Assays. Methods in Enzymology. Volume 406. Edited by William E. Balch CJD, Alan H: Academic Press. 2006:406:692-701

30. Fujisaka S, Usui I, Bukhari A, Ikutani M, Oya T, Kanatani Y, et al. Regulatory mechanisms for adipose tissue M1 and M2 macrophages in diet-induced obese mice. Diabetes. 2009:58:2574-82.

31. Lee G-S, Choi K-C, Han H-J, Jeung E-B. The classical and a non-classical pathways associated with NF- B are involved in estrogen-medicated regulation of Calbindin-D9k gene in rat pituitary cells. Mol Cell Endocrinol. 2007;277:42-50

32. Jakacka M, Ito M, Weiss J, Chien P-Y, Gehm BD, Jameson JL. Estrogen receptor binding to DNA is not required for its activity through the nonclassical AP1 pathway. J Biol Chem. 2001;276:13615-21.

33. Kumar D, Hosse J, von Toerne C, Noessner E, Nelson PJ. JNK MAPK pathway regulates constitutive transcription of CCL5 by human NK cells through SP1. J Immunol. 2009;182:1011-20.

34. Lucia MS, Torkko KC. Inflammation as a target for prostate cancer chemoprevention: pathological and laboratory rationale. J Urol. 2004;171: S30-34. discussion S35.

35. Nelson WG, De Marzo AM, Isaacs WB. Prostate cancer. N Engl J Med. 2003; 349:366-81

36. De Marzo AM, Marchi VL, Epstein JI, Nelson WG. Proliferative inflammatory atrophy of the prostate: implications for prostatic carcinogenesis. Am J Pathol. 1999;155:1985-92.

37. Balkwill F. Cancer and the chemokine network. Nat Rev Cancer. 2004:4: 540-50. 
38. Ronnov-Jessen L, Petersen OW, Bissell MJ. Cellular changes involved in conversion of normal to malignant breast: importance of the stromal reaction. Physiol Rev. 1996;76:69-125.

39. Guo X, Oshima H, Kitmura T, Taketo MM, Oshima M. Stromal fibroblasts activated by tumor cells promote angiogenesis in mouse gastric cancer. J Biol Chem. 2008:283:19864-71.

40. Camp JT, Elloumi F, Roman-Perez E, Rein J, Stewart DA, Harrell JC, et al. Interactions with fibroblasts are distinct in Basal-like and luminal breast cancers. Mol Cancer Res. 2011;9:3-13.

41. Camps JL, Chang SM, Hsu TC, Freeman MR, Hong SJ, Zhau HE, et al. Fibroblast-mediated acceleration of human epithelial tumor growth in vivo. Proc Natl Acad Sci U S A. 1990;87:75-9.

42. Stetler-Stevenson WG, Aznavoorian S, Liotta LA. Tumor cell interactions with the extracellular matrix during invasion and metastasis. Annu Rev Cell Biol. 1993:9:541-73.

43. Balkwill FR, Mantovani A. Cancer-related inflammation: common themes and therapeutic opportunities. Semin Cancer Biol. 2012;22:33-40.

44. Mueller L, von Seggern L, Schumacher J, Goumas F, Wilms C, Braun F, et al. TNF-alpha similarly induces IL-6 and MCP-1 in fibroblasts from colorectal liver metastases and normal liver fibroblasts. Biochem Biophys Res Commun. 2010:397:586-91.

45. Silzle T, Kreutz M, Dobler MA, Brockhoff G, Knuechel R, Kunz-Schughart LA. Tumor-associated fibroblasts recruit blood monocytes into tumor tissue. Eur J Immunol. 2003;33:1311-20.

46. Robinson SC, Scott KA, Wilson JL, Thompson RG, Proudfoot AE, Balkwill FR. A chemokine receptor antagonist inhibits experimental breast tumor growth. Cancer Res. 2003;63:8360-5.

47. Sica A, Mantovani A. Macrophage plasticity and polarization: in vivo veritas. J Clin Invest. 2012;122:787-95.

48. Comito G, Giannoni E, Segura CP, Barcellos-de-Souza P, Raspollini MR, Baroni $\mathrm{G}$, et al. Cancer-associated fibroblasts and M2-polarized macrophages synergize during prostate carcinoma progression. Oncogene. 2014;33:2423-31.

49. Chen M, Yeh CR, Chang HC, Vitkus S, Wen XQ, Bhowmick NA, et al. Loss of epithelial oestrogen receptor a inhibits oestrogen-stimulated prostate proliferation and squamous metaplasia via in vivo tissue selective knockout models. J of Pathology. 2012;226:17-27.

50 Ricke WA, McPherson SJ, Bianco JJ, Cunha GR, Wang Y, Risbridger GP. Prostatic hormonal carcinogenesis is mediated by in situ estrogen production and estrogen receptor alpha signaling. FASEB J. 2008;22:1512-20.

51. Attia DM, Ederveen AG. Opposing roles of ERalpha and ERbeta in the genesis and progression of adenocarcinoma in the rat ventral prostate. Prostate. 2012;72:1013-22.

52. Royuela M, de Miguel MP, Bethencourt FR, Sanchez-Chapado M, Fraile B, Arenas $\mathrm{Ml}$, et al. Estrogen receptors alpha and beta in the normal, hyperplastic and carcinomatous human prostate. J Endocrinol. 2001;168:447-54.

53. Celhay O, Yacoub M, Irani J, Dore B, Cussenot O, Fromont G. Expression of estrogen related proteins in hormone refractory prostate cancer: association with tumor progression. J Urol. 2010;184:2172-8.

54. Platz EA, De Marzo AM. Epidemiology of inflammation and prostate cancer. J Urol. 2004;171:S36-40.

55. Prins GS, Birch L, Couse JF, Choi I, Katzenellenbogen B, Korach KS. Estrogen imprinting of the developing prostate gland is mediated through stromal estrogen receptor alpha: studies with alphaERKO and betaERKO mice. Cancer Res. 2001;61:6089-97.

56. Van Laere SJ, Van der Auwera I, Van den Eynden GG, van Dam P, Van Marck EA, Vermeulen PB, et al. NF-kappaB activation in inflammatory breast cancer is associated with oestrogen receptor downregulation, secondary to EGFR and/or ErbB2 overexpression and MAPK hyperactivation. Br J Cancer. 2007; 97:659-69.

57. Spence RD, Wisdom AJ, Cao Y, Hill HM, Mongerson CR, Stapornkul B, et al. Estrogen mediates neuroprotection and anti-inflammatory effects during EAE through ERalpha signaling on astrocytes but not through ERbeta signaling on astrocytes or neurons. J Neurosci. 2013;33:10924-33.

58. Zhang GJ, Adachi I. Serum interleukin-6 levels correlate to tumor progression and prognosis in metastatic breast carcinoma. Anticancer Res. 1999;19:1427-32.

59. Yadav A, Kumar B, Datta J, Teknos TN, Kumar P. IL-6 promotes head and neck tumor metastasis by inducing epithelial-mesenchymal transition via the JAK-STAT3-SNAIL signaling pathway. Mol Cancer Res. 2011;9:1658-67.

60. Michalaki V, Syrigos K, Charles P, Waxman J. Serum levels of IL-6 and TNFalpha correlate with clinicopathological features and patient survival in patients with prostate cancer. Br J Cancer. 2004;90:2312-6.
61. Lou W, Ni Z, Dyer K, Tweardy DJ, Gao AC. Interleukin-6 induces prostate cancer cell growth accompanied by activation of stat3 signaling pathway. Prostate. 2000;42:239-42.

62. Hsu CP, Chen YL, Huang CC, Chou CC, Liu CL, Hung CH, et al. Antiinterleukin-6 receptor antibody inhibits the progression in human colon carcinoma cells. Eur J Clin Invest. 2011;41:277-84.

63. Naugler WE, Sakurai T, Kim S, Maeda S, Kim K, Elsharkawy AM, et al. Gender disparity in liver cancer due to sex differences in MyD88-dependent IL-6 production. Science. 2007;317:121-4.

64. Chen M, Hsu I, Wolfe A, Radovick S, Huang K, Yu S, et al. Defects of prostate development and reproductive system in the estrogen receptor-alpha null male mice. Endocrinology. 2009;150:251-9.

\section{Submit your next manuscript to BioMed Central and we will help you at every step:}

- We accept pre-submission inquiries

- Our selector tool helps you to find the most relevant journal

- We provide round the clock customer support

- Convenient online submission

- Thorough peer review

- Inclusion in PubMed and all major indexing services

- Maximum visibility for your research

Submit your manuscript at www.biomedcentral.com/submit

) Biomed Central 